\title{
Mainstreaming Geography's Decolonial Imperative
}

\author{
Tariq Jazeel (UCL)
}

1. The theme of this year's RGS/IBG conference takes the form of a call to our discipline. Decolonizing geographical knowledge urges us to engage 'minor' or 'southern' knowledges. It demands disciplinary geography interrogate its own teleology of intellectual progress, and it implicates geographers in cultures of academic knowledge production that remain tethered to the particularities and political economies of Anglophone geography just as they make implicitly universal claims. That the Royal Geographical Society have chosen to support this theme is a refreshing admission of what many in the discipline have long been aware: Geography has a way to go before it can claim to have transcended its imperial histories. As such, the theme places before the conference's ever-expanding community a challenge that the disciplinary 'we' implied by the call's very formulation must, I feel, welcome.

The prospect of confronting the challenge to decolonize our discipline is as dizzying as it is complex. It necessitates as many difficult conversations about teaching and curriculum planning as it warrants critical engagements with our discipline's imperial histories and theory-culture. Given the Herculean task ahead, efforts at decolonizing geographical knowledge will not be straightforward. Action must be practical, methodological and theoretical. It must be collective, cautious, confrontational and unfailingly tentative, unafraid to fail that is to say. Indeed Gayatri Spivak's (1988) literary theoretical critique of subaltern history writing teaches us that failure will be inevitable; attempts to decolonize geography will always leave evermore-subaltern residues.

But perhaps the real value of the conference theme is its assertion that the task of decolonizing geographical knowledge is now too important to be left to subfields like postcolonial geography alone. Indeed, if the theme is a call to our discipline, it is also a particular kind of mainstreaming; it invites us all as disciplinary geographers to share what the anthropologist David Scott calls a 'problem space'. For Scott (2004, p.4), a 'problem space' constitutes "a context of argument, and, therefore, one of intervention", and hence "from within the terms of any given problem-space what is 
in dispute... is not itself being argued over." The performative effect of this imperative-made-conference-theme is that the ongoing coloniality of geographical knowledge production is not only widely accepted, it is also now every geographer's problem. That is to say, the mainstreaming of this call precipitates a collective awareness that geography's decolonial imperative concerns us all, and an equally collective responsibility to think together to do something about the inconvenient truth of coloniality at large in our discipline. This in itself is a legitimization of the concerns of geographers who have struggled for years at the intersections of, for example, postcolonial and subaltern studies, black studies and critical indigenous theory, queer and feminist theory. And in my most optimistic moments, I want to believe that mainstreaming the decolonization imperative means confronting marginalization will no longer be left only to those who occupy marginal positions within the discipline; that it will precipitate many acts of decolonization from the multiply situated 'we' in our discipline today.

2.

I write, of course, within a workplace engaged in the ideological production of neo-colonialism even through the influence of such thinkers as Foucault.

(Gayatri Spivak 1985, p.349)

Inevitably, however, there is a danger that mainstreaming the decolonization imperative will merely establish a new kind of theoretical orthodoxy. Indeed, the tensions that inhere in the task of decolonizing geographical knowledge can be evoked by some brief elaboration on the antagonistic conversations between postcolonial theory and decolonial scholarship. Anglophone geography is by now familiar with the influence that the former continues to have in shaping our efforts to negotiate the colonial present. Indeed, postcolonial geography is by now an established sub-disciplinary field, buttressed as it is -by an increasing number of specialist undergraduate and graduate modules, books, handbook chapters, review essays, workshops, and now even a dedicated book series at Routledge. I have been part of this creeping consolidation of the subfield. Yet here is my confession. As committed as I am to working at the intersections of critical geography and postcolonial theory, I am deeply suspicious of postcolonial geography's 
professionalization. As Vinay Gidwani (2008, p.237) reminds us, "in the academic context what counts as use-value is governed by the regulative ideals of the prevailing academic canon", and let us be clear that postcolonial geography is now part of our disciplinary canon. My point is that postcolonial geography's canonization alse-risks its prescriptive stultification as theoretical orthodoxy. What I want to stress therefore is that we must remain continually vigilant against the authoritative prescription of any "correct theoretical practice" (Spivak 1985, p.346) for decolonizing geographical knowledge, because it is precisely the representational containment of geography's theoretical orthodoxies that battens the hatches against the outside, the minor, the excluded. In other words, postcolonial geography must itself be situated within the political economy of academic knowledge production.

To this extent, the Modernity/Coloniality/Decoloniality (MCD) research programme, from which the conference theme's decolonial imperative claims some provenance, poses a useful reminder of the double bind that decolonizing geographical knowledge places us in. Emerging from Latin Americanist scholars Anibal Quijano, Maria Lugones, Walter Mignolo and others, this work points to the European conquest of Latin America as that which marked the beginning of the constitution of a new world order that, five hundred years later, has resulted in a global power covering more or less the whole planet. If this process has resulted in what Quijano (2007, p.168) refers to as the violent concentration of the world's resources under the control and for the benefit of a historically privileged European and North Atlantic minority, then academic knowledge production, even its critical leftist incarnations, is irreducibly part of this dispositif. Theory is commodity. For Mignolo (2002), the result is a distinct geopolitics of knowledge wherein critique, including its postcolonial theoretical variants, emerges from within a modernist project which itself is inseparable from coloniality. As Mignolo (2002, p.64) writes, "the planetary expansion of the social sciences implies that intellectual colonization remains in place, even if such colonization is well intended, comes from the left, and supports decolonization." Perhaps the key difference then between postcolonial theory and decoloniality scholarship, at least as some decolonial scholars have it, is that the decolonial shift is a project of de-linking, whereas postcolonial theory is a project of scholarly transformation within the academy (Asher 2013, p.835).

For the decolonialists then, North Atlantic scholarship faces a double bind insofar as decolonization, conceived as the dismantling of modernity's power 
structures, will never be achieved from within its own theoretical orthodoxies and infrastructures. In Audre Lord's (1983) idiom, 'The master's tools will never dismantle the master's house'. Decoloniality scholarship thus looks toward the academy's outside, to its beyond, for the practical and methodological decolonization of theoretical modernity. It looks to 'indigenous' and 'southern' thinkers for epistemic perspectives and cosmologies that have heretofore been obscured by Eurocentric rationality (Asher 2013, p.835), just as it interrogates the coloniality of the representational containment of thinkers via the very adjectival prefixes 'indigenous' and 'southern'.

In truth, the traction between decolonial scholarship and postcolonial theory is somewhat overemphasized. The epigraph to this section should alert us to how certain strands of postcolonial theory have always negotiated precisely this double bind and the implications it has for anti-colonial politics. Indeed, Gayatri Spivak has been persistent and insistent about this tension, such that her 1999 book is explicitly tabled as $A$ Critique of Postcolonial Reason; a title that implies the necessary and perennial movement toward ever-more-equitable conjunctures. Furthermore, as Kiran Asher (2013, p.839) writes, it is not as if the double bind does not impinge on decolonial scholarship itself. Its authors seem to want to disavow the institutionalization of their own work as theoretical paradigm, yet Mignolo and co. persistently fall into the trap of equating their political aims with theory.

Notwithstanding these correctives, decoloniality's warning about the professionalization of critical engagements with a theoretical modernity congruent with coloniality is useful. It reminds us that mainstreaming the call to decolonize should not lead us to merely settle for more finely honed theoretical debates at one of Anglophone geography's 'leading' intellectual gatherings when that very gathering, or those-increasingly esoteric theoretical debates, will ultimately remain out of the reach of many. Decolonizing geographical knowledge requires more. It requires us to think carefully about how to de-link the production of geographical knowledge from the hegemony of our disciplinary infrastructure. And the RGS/IBG annual meeting is unequivocally part of that infrastructure. The awkward question this precipitates then is how compatible the call is with the infrastructure of the annual conference and its protocols as it stands? What kinds of pay-walls (monetary and non-monetary) will remain in place to further reify the 'we' earnestly debating geography's decolonial imperative come late August 2017? 
3. But this raises another important question: 'why decolonize?', or 'for whose benefit is this imperative?' To tackle this, we might usefully remember that the aim of the conference theme is not only decolonizing geographical knowledge, it also promulgates opening geography to the world. For sure we can read in this the trace of a decolonial injunction to learn from southern knowledges. But opening geography to the world also demands that geographical knowledge might have something of relevance to say to that world, that it might 'speak to' places, peoples and communities in politically germane ways. That it might intervene. This, I want to suggest, is a useful injunction insofar as it should prompt us to think about the 'so what?' of geographical knowledge production, decolonized or not. In other words, why would each of us feel that the world wants to listen to our disciplinary iterations?

My point here is that if the decolonial imperative urges a more cosmopolitan theoretical habitus within our discipline, that does not in itself attend to the ways that a hypothetically more cosmopolitan academic geographical canon will continue to play a regulative role in producing the exchange-value of geographical work. In the face of a more planetary disciplinary canon, we might content ourselves that 'we now practice a worldly geography, we listen to those we didn't listen to before, and therefore we can now feel better about ourselves. Job done.' But incorporation alone does little to re-orient our iterations outwards, towards critical readerships based either in the places on which we work, or in the area studies communities relevant to our research. The imperative to open geography to the world demands we do more. It demands that we as a disciplinary community have something we think worth saying to that world in its myriad singularities. If decolonizing geographical knowledge is then to be a common disciplinary 'problem space', it is one that should also help us delineate contexts of intervention through the injunction to open our geographical iterations out to the world.

Elsewhere I have written on the dangers of a disciplinary overspecialization that, if unchecked, can pull geographers away from the particularities of field contexts and accountability to those particularities (Jazeel 2016). As I have argued, the effort to make ourselves relevant as geographers within area studies communities and within the field contexts in which we work necessitates ways of re-orienting our critical iterations outwards. Just as the call Decolonizing geographical knowledge: opening geography out to the world demands a pluralization of voices within our 
disciplinary community, it also demands an ethical imperative to 'abide by' the places on which we work, to intervene in debates that may in fact be of little concern at conferences like the RGS/IBG annual meeting that constitutes Anglophone geography's leading edge, yet matter elsewhere. Mainstreaming the decolonial imperative in Geography demands that we attend to those elsewheres, even if it means we might become a little more ambivalent about our discipline in the process. 


\section{Bibliography}

Asher, K. (2013) 'Latin American Decolonial Thought, or Making the Subaltern Speak', Geography Compass 7, pps.832-842

Gidwani, V. (2008) Capital Interrupted: agrarian development and the politics of work in India, University of Minnesota Press: Minneapolis

Jazeel, T. (2016) 'Between area and discipline: progress, knowledge production and the geographies of geography', Progress in Human Geography 40 (5), pps.64967

Lorde, A. (1983) 'The Master's Tools Will Never Dismantle the Master's House', in C. Moraga and G. Anzaldua [eds.], This Bridge Called my Back: writings by radical women of colour, Kitchen Table Press: New York, pps.94-101

Mignolo, W. D. (2002) 'The Geopolitics of Knowledge and the Colonial Difference', The South Atlantic Quarterly 101 (1), pps.57-96

Quijano, A. (2007) 'Coloniality and Modernity/Rationality’, Cultural Studies 21 (23), pps.168-78

Scott, D. (2004) Conscripts of Modernity: the tragedy of colonial enlightenment, Duke University Press: Durham

Spivak, G. C. (1985) 'Subaltern Studies: deconstructing historiography', in R. Guha [Ed.], Subaltern Studies IV: writings on South Asian history and society, Oxford University Press: New Delhi, pps.330-363

Spivak, G. C. (1988) 'Can the Subaltern Speak?', in C Nelson and L Grossberg [Eds.], Marxism and the Interpretation of Culture, MacMillan: London, pps.271-313 